\title{
The Impacts of Organizational Culture and Transformational Leadership Style on The Employee's Job Performance: A Case Study at UAE's Petrochemical Company
}

\author{
Aishah AL DHANHANI and Nor Hazana ABDULLAH \\ Universiti Tun Hussein Onn Malaysia (UTHM) Parit Raja, Batu Pahat, Johor, Malaysia \\ Correspondence should be addressed to: Aishah AL DHANHANI; aishaaldhanhani76@gmail.com \\ Received date:28 August 2019 ; Accepted date:3 December 2019; Published date: 26 June 2020 \\ Academic Editor: Olivia Fachrunnisa
}

Copyright (C) 2020. Aishah AL DHANHANI and Nor Hazana ABDULLAH. Distributed under Creative Commons Attribution 4.0 International CC-BY 4.0

\begin{abstract}
Organizational culture is a system of shared meaning held by members which distinguishes the organization from other organizations. Every organization is defined and characterized by its own culture and can barely be separated from its culture. Thus, the focus of this paper is on organizational culture transformational leadership style and job performance. Hence, to derive meaningful coverage, this study examines Abu Dhabi National Oil Company (ADNOC). This oil and gas sector plays an important role in the national economic development of the United Arab Emirates (UAE). In this quantitative research study, a structured questionnaire using a 5-point Likert scale was used as the instrument for data collection with a total of 450 respondents from Abu Dhabi National Oil Company participating in the study. The validity and reliability of the measurement and the structural models were ascertained. The Partial Least Squares Structural Equation Modeling (PLS-SEM) was used to test the hypotheses. Findings revealed that organizational culture and transformational leadership have significant relationship with employees' job performance. The findings add to the extant literature by integrating the factors that could improve job performance. Likewise, the implication for the practices and future research were also discussed.
\end{abstract}

Keywords: Transformational Leadership, organizational culture, job Performance, oil and gas company, UAE

Cite this Article as: Aishah AL DHANHANI and Nor Hazana ABDULLAH (2020)," The Impacts of Organizational Culture and Transformational Leadership Style on The Employee's Job Performance: A Case Study at UAE's Petrochemical Company", Journal of Human Resources Management Research, Vol. 2020 (2020), Article ID 379522, DOI: 10.5171/2020.379522 


\section{Introduction}

In today's society, the flow of life depends on effective leadership in several aspects such as; organizations development, survival of community, work function and effective performance. Organizations have been established to address social needs and group activities. Moreover, the current global economy is constantly driven by innovation, performance and profitability. NawoseIng'ollan, \& Roussel, (2017) note that due to globalization, companies are changing their structure in order to compete in the bigger global arena. Thus, organizations have to put more efforts in terms of providing job satisfaction. With numerous job opportunities currently available, candidates are difficult to please. They are looking not only for an attractive wages, but talents are choosing organizations that can provide them various kinds of benefits, the potential career advancement, and an environment in which they feel comfortable to learn and thrive. If an organization failed to fulfill these requirements, job seekers may find another company that does. Thus, it is important for organizations to understand exactly what they can offer to potential employees, then highlight their best features when recruiting candidates.

In general, leadership style is the behaviour pattern of a person who attempts to influence others (Northouse, 2012). The central concept here is change and the role of leadership in envisioning and implementing the transformation of organizational performance. Likewise, transformational leadership is simply the practice of leadership behaviour which empowers followers to create a vision, promote change, and achieve a meaningful and satisfying work environment (Bass, 1985). Transformational leadership attributes include four transformational elements which include Idealized influence, Inspirational motivation, Individualized consideration and Intellectual stimulation (Avolio, 1991) Gopal and Chowdhury, 2014). Similarly, Simmons et al.
(2017) explains that a leader is an individual or group of people who decides on, equips, trains, and influences one or more followers who have diverse attributes, competencies, and talents and focuses on developing such followers for organizational tasks and objectives. He also inspiresthe followers to willingly and enthusiastically expend emotions physical and mental energy in a concentrated and coordinated effort to attain the organizational goals and targets. Finally, leadership is defined as the process of influencing the activities of an organization in the form of goal attainment (Kişi, 2019). It is also the manner of facilitating employees and their collective efforts to perform shared objectives; and the manner by which they are influenced to agree on what needs to be carried out and the way they are to be carried out (Yukl, 2010; Northouse, 2007; Janićijević, 2008).

According to Denison, Hooijberg, Lane, \& Lief, (1996) organizational culture is defined as the underlying values, beliefs, and principles that serve as a foundation for an organization's management system, as well as the set of management practices and behaviours that both exemplify and reinforce those basic principles. Denison (1996) conceptualizes organizational culture as composed of four major dimensions, including: involvement, consistency, adaptability and mission. It is, thus, evident that organizational culture contributes to organizational effectiveness andreflects the strategy, leadership and practices of an organization; it is the means by which members of an organization express themselves, and it is the glue that binds a distinct group of individuals together all in an effort of achieving a common vision and goal. The organizational culture has been depicted as being responsible for being associated with employee job performances, since the culture of an organization is evidently: the translation of organizational vision, strategy, leadership and systems into organizational practices that either lead to success or failure within the organization 
(Denison, Nieminen and Kotrba, 2014). Furthermore, Tlaiss \& Elamin (2015) determined the relationship between organizational culture and overall job performance in a manufacturing firm in Kuching, Sarawak (Malaysia). Using a convenient sampling of one hundred thirty-five respondents and face-to-face interview, data were collected and analyzed using the Statistical Package for Social science (SPSS). Findings from the study revealed that there was a significant relationship between cultural norms, cultural values, culture and compensation structures, and the overall performance of the employees are arguably the most important asset within an organization as they play pivotal roles in achieving organizational goals and target, consequently, creating value for the future.

Transformational leadership has become a crucial leadership style for modern organizations given the impact such leadership has on organizational related outcome and variables. Devanna (1990) states that transformational leaders are agents of change who are able to create innovative and flexible work environments that inspire employees to achieve results beyond their intended capacity. Given the volatile nature of gas industry in terms of fluctuating prices of oil, as well as, the rigors of managing a diverse human resource capital and facilities found in oil and gas companies, it becomes crucial that leaders with the right leadership behaviour and qualities mange the affairs of oil and gas operations within organizations. The literature has revealed that leaders who are able to respond to changes and initiate change that outweighs expected outcomes are those who possess transformational leadership qualities (Ahamad \& Kasim, 2016; Barling, Slater, \& Kevin Kelloway, 2000; Biswas, 2009; Chang et al., 2017; Esmi, Piran, \& Hayat, 2017; Musa et al., 2018; Wang et al., 2005). Hence, transformational leadership becomes increasingly important for the leadership of oil and gas companies.
The Abu Dhabi National Oil company is UAEs foremost and largest oil and gas company and is the most contributor to economic development in the UAE among all public organizations. In the Sustainability Performance report (2015) of the Abu Dhabi National Oil Company, it was revealed that over 65,000 employees were employed in the organization, with a significant proportion of those employees, Emiratis. Similarly, the report revealed that ADNOC patronizes over 165000 local contractors, and a total of AED 309 million on the training of employees to develop the core values of the organization and contribute significantly to the economic development of the UAE (Taing and Way, 2015). This further reiterates ADNOC's crucial role in the sustenance of the UAE economy. However, it was reported that ADNOC spends significantly on training and development of its employees in order to scale up employee performance, consequently leading to developing the overall organizational performance. While the training and development of employees are crucial, it can, however, be directed towards developing the core leadership skills and attributes in employees that build on employee performance, while nurturing an organizational culture with which performance thrives. Sadly, no study in the UAE has explored or examined the effect of organizational culture and transformational leadership style on the employee's job performance, especially from an oil and gas context (Alzahmi, 2016; Hijazi, 2017; Saad \& Abbas, 2018). Hence, since ADNOC is required to deliver a set of targets and objectives, to do so, effective leadership and administration would be required across all of the company's operations, as well as the contributions of employees to achieve the desired performance the company seeks from all of its members. There is an evidence suggesting that transformational leadership influences the job performance of employees (Ahamad \& Kasim, 2016; Antonakis \& House, 2002; Biswas, 2009; Chang et al., 2017; Devanna, 1990; Eisenbach, Watson, \& Pillai, 2009; Elrehail et al., 2018; Enwereuzor, Ugwu, \& Eze, 2018; Khasawneh, Omari, \&

Aishah AL DHANHANI and Nor Hazana ABDULLAH (2020), Journal of Human Resources Management Research, DOI: 10.5171/2020.379522 
Abu-Tineh, 2012; Musa et al., 2018). However, it is not known from the gulf countires perspective, especially, in the oil and gas context. Hence, this study examined the influence of organizational culture and transformational leadership style on the employees job performances of Abu Dhabi National Oil Company employees.

\section{Literature Review}

\section{Organizational culture}

The term culture has become an important part of all human societies. With the emergence of globalization, culture has taken on a broader meaning and has evolved into an indispensable dimension for organizations (Browaeys \& Price, 2008). Culture, in its simplest form, is described as the way of life of a group of people (Foster, 1962). Hofstede (2011) defines culture "as the collective programming of the mind that distinguishes members of a group or category from others". Organizational culture, on the other hand, may be defined as the collective programming of the minds of organizational members to hold certain beliefs, norms and values. In the words of Schein (2010); Warrick (2017); Zhou (2017) and Mohamed (2016), organizational culture is described as comprising an underlying set of norms, values, and assumptions that members of an organization hold that depicts the organizations visions, missions and beliefs. Hence, the organizational culture of the company would align this value and belief with the reward system and processes. Employees who are fairly treated reciprocate by performing well in the jobs given to them. Likewise, empirical evidence suggests that organizational culture is indeed a construct of analysis in several studies (Dastmalchian et al., 2000; Berrio, 2003; Yang, 2010; Keir and Youssif, 2016; Halim, Alremawi, \& Tambi, 2018) For example, Abdullah et al (2014) reported the significant role of organizational culture as a compass for guiding the behaviour of employees. Halim et al. (2018) examined the role of organizational culture in the relationship between leadership style, organizational commitment, quality management practices and organizational performance. Findings from the study revealed that organizational culture mediated the relationship between organizational factors and organizational performance. Al-Ali et al (2017) also examined the influence of change leadership on organizational culture and change management practices in the public-sector firms in the UAE. The study also reports the role of organizational culture (hierarchical culture) on the interactions between leadership and change management programmes. Furthermore, findings from the study revealed that hierarchical culture was positively and significantly impacting both planned and emergent change management in UAE public sector service organizations.

Additionally, Esmi, Piran, and Hayat (2017) examined the effect of organizational culture on the relationship between transformational leadership and organizational citizenship behaviour. Findings revealed that two dimensions of transformational leadership, i.e. individualized consideration and inspirational motivation, directly influenced organizational citizenship behaviour positively through the role of involvement (a dimension of organizational culture). Findings further show that the other two dimensions of transformational leadership (i.e. intellectual stimulation, and idealized influence) only directly influence organizational citizenship behaviour and through the mediating role of involvement also. Similarly, Abdullah et al (2013) explored the role of organizational culture in the relationship between leadership values and innovations in organizations. Findings confirm that organizational culture influences the relationship between leadership value and innovations. The role of organizational culture in the extant literature is evident. However, much of these literatures have not focused on non-western context as well as in oil and gas companies. Some studies have recommended the examination of the organizational culture in 
the relationship with organizational variables such as leadership and performance in non-western context in order to provide empirical evidence of the role of organizational culture and transformational leadership style in non-western context (Wang et al., 2005; Halim et al., 2018; Saad and Abbas, 2018).

\section{Leadership}

Leadership is related to change. Northouse $(2010 ; 2018)$ defines leadership as a procedure wherein an individual impacts a group of people to achieve the same goal. Similarly, Bennett et al., 2017 and Batmanghlich, (2015) describe leadership as the influential relationship between leaders and follower inspiring significant changes that replicate their interactive functions. Leaders themselves tend to be under a lot of pressure, while they may be new to the problem that they face, they intend to generate significant changes in an effort to prove their worth and impact on the organization. Western, (2008) additionally explains that leadership management is a technique whereby a leader focuses on understanding and relating with subordinates or followers while assisting them in outlining their values and dreams, thereby motivating them to achieve organizational goals (Storey et al., 2016).

Since the early 20th century, scientific research on leadership emerged. A large number of studies demonstrated that leadership had gained significant importance, from education and business to social organizations (Al-Husseini, 2014). Scholars have found that leadership behaviours are essential factors that lead to the success of organizations (Bass, 1990; Al-husseini, 2014). Nowadays, organizations need to have people with high ability in leadership that can contribute to the success of the occupation (Northouse, 2007). Likewise, AlHusseini (2014) stated that a good leader has the ability to transform the organization according to the market demands, as this is a solution to most of the organizational issues today. In addition, effective leaders have the functionality and capability to steer organizations to fulfilment by attempting and paying attention to the envisioned long-term commercial enterprise or environmental exchange (Avolio, Waldman, and Yammarino, (1991).

Northouse (2007) pointed out that for an organization to build an efficient team, it is necessary to have an effective leadership as it is by far one of the crucial elements in enhancing the performance of the organization. Those who have the potential to affect individuals are known as leaders, and those whom the characteristic of management is applied to are referred to as the supporters. Leaders and followers are linked to the process of leadership (Northouse, 2007). Hence, Nawaz, \& Khan (2015) saw leadership as the influence that occurs between leaders and his/her subordinates, which consequently produces excellent results. These definitions and discussions on leadership help to conceptualize exactly what the term leadership means, as well as how it can be approached within organizational settings. In conclusion, these definitions of leadership evidently reveal that leadership entails some form of exchange, it is between two groups of people (usually leaders and followers), working together towards a common goal. The entire leadership process is also characterized by specific abilities and qualities of leaders in inspiring and motivating followers to achieve organizational goals. Nawaz, \& Khan (2015) stated that the primary theories of leadership are transactional and transformational leadership theory, contingency theory, leader-member exchange (LMX) concept, traits theory, behavioural theory and decision concept of management. Some of these theories will be explored in the following section. 


\section{Transformational Leadership Style}

The concept of transformational leadership is based on charismatic leadership studies. The idea was developed from leadership research subjects (Tafvelin, 2013). Burns (1978) first related the idea of transformational leadership, which he described as "transforming leadership" at the time and subsequently was expounded by Bass (1996). According to Burns (1978), transforming leadership is a term that describes how leaders and followers help each other to reach an optimal level of morale and motivation, thus enabling organizational success. In trying to differentiate leadership and management practices, Burns (1978) also opined that some difficulty exists in separating the two concepts, but the later and the former can be distinguished with regards to their characteristics and behaviour, hence in such attempt, he established the concept of transforming and transactional leadership. Furthermore, Burns (1978) stated that the transforming approach to leadership focuses on two essential elements- people and the organization. It enables an avenue for organizational change and value by creating a sense of change in perception, expectations and aspirations of employees and by enabling leaders to better align employee's abilities and interest for the attainment of organizational goals. Transforming leadership is a leadership concept that is characterized by causing overall changes in organizational culture, through leadership by example, as well as a morale motivator and role model- that is the leader. In reaching a more conclusive description of the concept, transformational leadership is one in which leaders ensure ways of motivating followers (employees) to do more than they are possiblely expected to do, this is what the leader does according to Avolio, Bass, and Jung (1999) by increasing the sense of importance and value perception of tasks, stimulating employees to surpass their level of interest and direct such interest towards the goals of the organization, thereby raising the level of change also.
This leadership theory focuses on motivating employees to overcome their very own distractions and strive for the collective goals of the organization. Transformational leaders have the capacity to influence followers in such a way that they are able to adopt imaginative and discerning attributes for the benefit of the organization as though such attributes were always present in them (Jiang, et al., 2017). Hence, such leaders generally tend to help their followers to perform beyond expectations with the intention of making their vision come true (Bass, 1999; Avolio and Bass, 2004). In addition, this motivates employees to relinquish personal interests and strive for the attainment of collective organizational goals (Beck-Tauber, Choy Chong, and Wüstenhagen, 2012). Within the concept of transformational leadership, Bass (1996) argued that leaders must adopt the positive forms of transactional leadership (such as contingent reward and active management by exception) as well as transformational leadership. He explained that an integration of the two leadership styles would lead to optimal success in the organization. Conversely, Burns (1978) argued that leaders must strive for a transformational leadership style. Similarly, transformational leadership accounts for unique variance in performance ratings (or other consequences) (Bass, 2000; Tafvelin, 2013).

\section{Job Performance}

The word "performance" is used extensively in all fields of management research. Golden (2016) argues that organizations are judged mostly by their performance. Thus, the achievement of any business organization is continuously dependent on the contribution from employee's job performance. The performance of the employees is highly responsible for realizing the vision and mission of the business organization. Therefore, it is essential for leaders and employees to understand the concept behind job performance. On the other hand, job performance implies the measurable 
outcomes of employees regarding their effort which is associated with the business organizations' goals and objectives which are accomplished by the employees when they work effectively and efficiently. In addition, job performance is an indication of the capacity of an organization to efficiently accomplish independent objectives (Muda, Rafiki, and Harahap, 2014). Some of the components that are considered measurable are employees' performance, which is measured by their level of production. Numerous studies have established various ways of assessing job performance (Saad and Abbas, 2018). This includes determining the quality, quantity, knowledge and/or creativity of individuals as against the accomplished task which has been defined and specified in the employee's job description to be carried out over a specified time (Mawoli et al., 2012).

Weerarathna and Geeganage (2014) carried out a study to investigate the association between organizational culture and job performance using a self-administered survey. Findings from the study revealed a significant positive correlation between organizational culture and job performance. Furthermore, Saad and Abbas (2018) examined the direct and indirect effect of organizational culture on the overall job performance of employees in the public sector in Saudi Arabia. The authors also examined the effect of each dimension of organizational culture on employees' job performance. Hence, the findings indicate a significant and positive relationship between organizational culture and employees' job performance. Likewise, four dimensions of organizational culture (i.e. managing change, achieving goals, coordinating teamwork and cultural strength) were significantly and positively correlated with job performance, with the exception of one organizational culture dimension (i.e. customer orientation) which was negatively associated with Job performance. The implication of the findings revealed that some organizational culture practices had a positive effect on performance while some also negatively influence job performance (Mawoli et al., 2012). As shown from a review of some of the studies in the extant literature, the association between organizational culture and job performance is evident. However, most of these studies were carried out in the western context. Furthermore, most of the empirical findings on the associations between organizational culture and job performance has been based on studies in private business companies and public companies (Hofstede, 2011; Saad and Abbas, 2018). Little research has been conducted in oil and gas companies on organizational culture and job performance, thus necessitating the need for this study.

\section{Research Framework}

Figure 1 shows the research framework of the study. After an extensive review of the literature. The researcher proposes the framework to guide the inquiry; the research framework provides an illustration of the map of the study by showing the variables being studied as well as the nature of the investigation. The dependent variable of the study is the job performance of middle managers in ADNOC, the independent variable of the study is transformational leadership style and the organizational culture.

$\mathrm{H}_{1}$ : There is a significant positive relationship between Organizational Culture and Job performance.

$\mathrm{H}_{2}$ : There is a significant positive relationship between transformational leadership and job performance. 


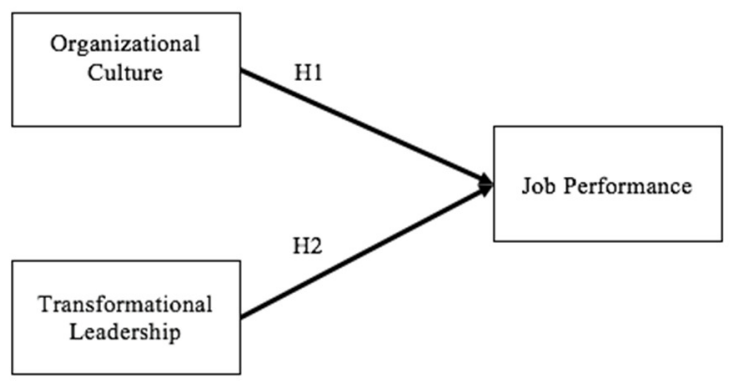

Figure 1: Research Framework

\section{Methodology}

This section focuses on the methodology adopted in this research study to find answers to the questions raised in the study. Thus, this study adopted the quantitative research approach; and therefore, the key instrument that was employed in the collection of data was a survey questionnaire. Likewise, this section includes an explanation of how the study was conducted and the selection of the respondents as well as the design of the questionnaire.

A convenience sampling technique was used to identify the sample for the study. The sample of 450 employees of middle managers of the oil and gas company middle managers participate as the respondents of the study. Three measurements were adopted; the transformational leadership (MLQ), Denison's Organizational Culture Survey and job performance; all items used 5 -Likert scales. The responses were coded as 1= Strongly Agree, 2= agree, 3= moderate, 4= disagree and $5=$ Strongly Disagree. The questionnaires were administered namelessly. Before distribution of the real data collection, pilot test was conducted and the reliability of the dimensions was determined. A Cronbach alpha value of above 0.7 represents acceptable level of internal consistencies. Therefore, all the constructs of the study were found to be reliable with Alpha Cronbach values ranging from 0.909 to 0.864. Upon completion of real data collection, Bootstrapping test was used to calculate the relationship between organizational culture and transformational leadership style on employees' job performance.

\section{Results}

The purpose of this exploratory sequential study is to examine the relationship between the organizational culture and the transformational leadership style on job performance in Abu Dhabi using ADNOC as case study. This section presents the findings obtained from the questionnaire deployed for the purpose of the research with a view to answering the research questions posed for the study.

\section{Discriminant Validity}

Discriminant validity is the degree to which scores on a given test do not correlate with scores from other tests that are not calculated to measure the same constructs. It is therefore assessed by analyzing constructs connections in any given model. Likewise, discriminant validity is said to be valid when each correlation is less than 1.0 by an amount greater than twice its respective 
standard error (Byrne, 2013; Hair, 2011). According to Fornell and Larcker (1981) and (Awang, 2015), discriminant validity is succeeded when the square root of a construct's Average Variance Extracted exceeds its correlation with other constructs. Table 1 is, therefore, intended to show the discriminate validity index of all the three constructs of the study.

Table 1: Discriminant validity index table

\begin{tabular}{|l|r|r|r|}
\hline \multicolumn{1}{|c|}{ Constructs } & $\begin{array}{c}\text { Job } \\
\text { Performance }\end{array}$ & $\begin{array}{c}\text { Organizational } \\
\text { Culture }\end{array}$ & $\begin{array}{c}\text { Transformational } \\
\text { Leadership Style }\end{array}$ \\
\hline Job Performance & $\mathbf{0 . 7 2 5}$ & & \\
\hline Organizational Culture & 0.632 & $\mathbf{0 . 6 2 3}$ & \\
\hline $\begin{array}{l}\text { Transformational } \\
\text { Leadership Style }\end{array}$ & 0.708 & 0.644 & $\mathbf{0 . 6 7 9}$ \\
\hline
\end{tabular}

The above Table 1 shows that the diagonal values in bold are the square roots of the Average Variance Extracted (AVE) of the latent constructs of the research. Thus, discriminant validity has been achieved among all the research constructs. As mentioned earlier this happens when the square root of a construct's AVE exceeds its relationship values with other constructs in the study (Awang, 2015).
Heterotrait-Monotrait (HTMT) analysis was used to support the proposal of Fornell and Larcker (1981). The HTMT analysis provides that discriminate validity is achieved when the inter-correlations between a constructs of interest with all other constructs is less than 0.85 (Kline, 2015). Therefore, it is confirmed that the discriminant validity in this study is succeeded, as presented in Table 2 .

Table 2: Heterotrait-Monotrait (HTMT) Ratio

\begin{tabular}{|l|r|r|r|}
\hline \multicolumn{1}{|c|}{ Constructs } & $\begin{array}{c}\text { Job } \\
\text { Performance }\end{array}$ & $\begin{array}{c}\text { Organizational } \\
\text { Culture }\end{array}$ & $\begin{array}{c}\text { Transformational } \\
\text { Leadership Style }\end{array}$ \\
\hline Job Performance & & & \\
\hline Organizational Culture & 0.678 & & \\
\hline $\begin{array}{l}\text { Transformational } \\
\text { Leadership Style }\end{array}$ & 0.747 & 0.716 & \\
\hline
\end{tabular}

Table 2 presented that all the values in the matrix are less than the 0.85 threshold for inter-constructs relationship, therefore the achievement of discriminate validity is confirmed as earlier explained the conditions. Thus, it can be safely concluded that the reliability and validity tests conducted on the measurement model are satisfactory. The analyses have confirmed that the measurement model for the study is valid, and is thus fit to be used to estimate the parameters of the structural model.

\section{Reflective Reliability Analysis}

The reliability of the study as shown in Table 3 has shown that Cronbach alpha ranges between .909 and .864 for the three identified variables. 
Table 3: Constructs Reliability and Validity

\begin{tabular}{|l|c|c|c|}
\hline \multicolumn{1}{|c|}{ Constructs } & $\begin{array}{c}\text { Cronbach's } \\
\text { Alpha }\end{array}$ & $\begin{array}{c}\text { Composite } \\
\text { Reliability }\end{array}$ & $\begin{array}{c}\text { Average Variance } \\
\text { Extracted (AVE) }\end{array}$ \\
\hline Job Performance & 0.909 & 0.923 & 0.525 \\
\hline Organizational Culture & 0.745 & 0.811 & 0.588 \\
\hline $\begin{array}{l}\text { Transformational } \\
\text { Leadership Style }\end{array}$ & 0.864 & 0.893 & 0.561 \\
\hline
\end{tabular}

All the Cronbach alpha values are above 0.7; this implies that the result is good and acceptable. If the alpha coefficient of any construct is less than 0.7 , it means that the Cronbach alpha value is below the acceptable margin and it should be looked into. The Cronbach alpha results illustrate that the entire constructs indicators have very good reliability, as shown in Table 3. In addition, all the constructs' indicators were above 0.7 . The item-total correlation is the correlation of the item with the total of other items in the scale (Aimran et al., 2015). SmartPLS is applied because the structural model is an important instrument for measuring the significance level of the path coefficients between the constructs. The analysis of the path coefficients is shown in Figure 2. The results have shown that there was significant positive relationship between transformational leadership style and organizational culture on employee's job performance.

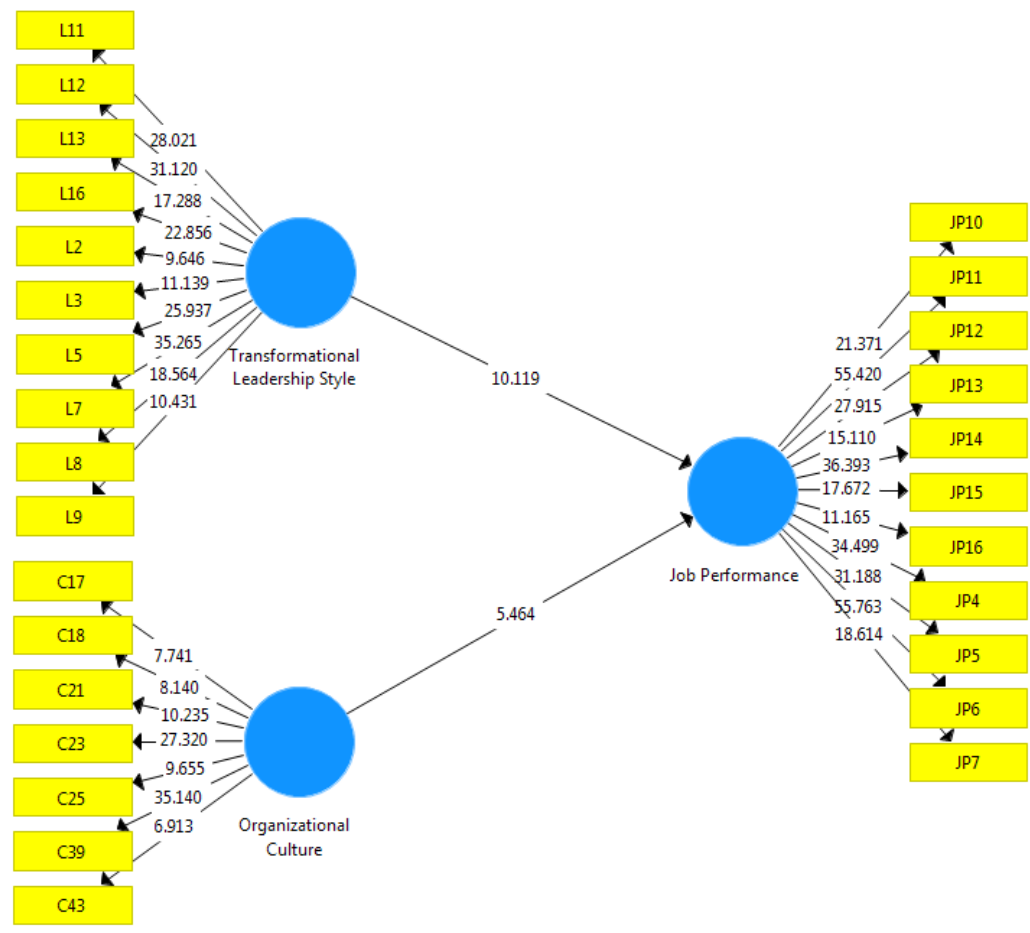

Figure 2: Structural model analysis 


\section{Path Coefficient}

According to (Hair, et al., (2014), the level or strength of a relationship is measured by the magnitude and significance of the estimates. Path coefficients that are close to +1 represent strong positive relationships while those that tend towards -1 represent strong negative relationships (Hair et al., 2014). The significance of the path estimates was determined using the bootstrapping method in Smart PLS-SEM.

Table 4: Significance test for the structural model path coefficient, $t$-statistics and $p$-values

\begin{tabular}{|l|c|c|c|c|c|}
\hline Path & Std $\boldsymbol{\beta}$ & $\begin{array}{c}\text { Std } \\
\text { Error }\end{array}$ & $\begin{array}{c}\boldsymbol{t} \\
\text { Statistic }\end{array}$ & $\boldsymbol{p}$-value & Decision \\
\hline $\begin{array}{l}\text { Organizational Culture } \\
\text {-> Job performance }\end{array}$ & 0.110 & 0.036 & 3.030 & 0.001 & Supported \\
\hline $\begin{array}{l}\text { Transformational } \\
\text { Leadership Style -> Job } \\
\text { performance }\end{array}$ & 0.232 & 0.020 & 11.513 & 0.000 & Supported \\
\hline
\end{tabular}

Table 4 shows the path coefficients for the various path model hypothesized in the model. Thus, it is evident that the 2 direct path coefficients of all were significant with $\mathrm{t}$ values exceeding the $\mathrm{t}$-critical value of 1.96 and $\mathrm{p}$-values value less than 0.05 . Both organizational culture and transformational leadership style had a strong positive relationship on employees' job performance hence, it can be said that there is a positive effect of organizational culture and transformational leadership style on the job performance of middle managers in ADNOC.

\section{Discussion}

The aim of the study is to scrutinize the effect of the organizational culture and transformational leadership style on employees job perforamance using ADNOC as the case study. Thus, the first research objective sought to determine the effects of organizational culture on job performance. Hypothesis (H1) was hence used to test the effect of organizational culture on job performance. Findings from the analysis revealed that there is a significant positive relationship between organizational culture and employee performance; hence, the hypothesis $\mathrm{H} 1$ was supported. This implies that the beliefs, assumptions, as well as values that define an organization also influence and impact organizational outcomes and performances. This finding is consistent with some studies reported in the literature. For instance, Weerarathna and Geeganage (2014) investigate the association between organizational culture and job performance using a self-administered survey. Findings from the study revealed a significant positive correlation between organizational culture and job performance. Similarly, Saad and Abbas (2018) examined the direct and indirect effect of organizational culture on the overall job performance of employees in the public sector in Saudi Arabia. The authors also examined the effect of each dimension of organizational culture on employees' job performance. Findings show a significant and positive relationship between organizational culture and employees' job performance. Hence, in this study, it is concluded that organizational culture has a significant and positive effect on the job performance of employees.

This result further supports the claim that leadership significantly affects organizational culture. Hence, the relationship between leadership style and organizational culture creates a strong determinant of job performance. This finding is consistent with 
that of Alomiri (2016) who found that National Culture mediates the relationship between leadership style and organizational culture, and it positively affects e-services implementation. Besides, Ahmadi, Rezaei, and Gorizan (2015) in his study, revealed that transformational leadership has a direct, positive and significant impact on organizational culture. This study further supports previous findings from Salanova (2011); Madhanga, C. S. M. (2018); Salleh, Mohamad \& Khalid (2018) which revealed that transformational leadership style has an impact on organizational culture. Findings from this study also corroborate those of James-Parks (2015) which showed that transformational leadership has a significant positive influence on organizational culture.

The second research objective sought to determine the effect of transformational leadership style on job performance. Hypothesis (H1) was therefore used to test the effect of transformational leadership style on job performance. Results from the analysis support the hypothesis that there is a significant positive relationship between transformational leadership and job performance. This implies that leadership plays a crucial role in the job performances of employees. This finding is corroborated by Golden (2016) in their study, which investigated the relationship between transformational leadership and the positive forms of transactional leadership on the job performances of TVE administrators in Nigeria. Findings revealed that transformational leadership and transactional leadership (i.e. contingent rewards and active management by exception) were positively and significantly correlated with employee job performance. Similarly, this finding is consistent with those of Jiang et al (2017) which investigated the effects of transformational leadership on sustainable job performance and found that transformational leadership positively affects sustainable job performance.

\section{Recommendations for Future Research}

Given the outcomes of this study, the following recommendation for future studies can be explored. Future studies can include more variables such as transactuional leadership, laissez-faire and other contextual variables to study the effects on job perfoamnce in different sactors. In addition, the present stusy has not used either mediation or moderation variables to see the indirect effect on job perfoamcne. Thus, it would be interestnting for future reschers to test the inrirect influence.

\section{Implications}

Findings from this study were established using a quantitative research approach, which uses numerical data to make an inference from a sample to a population. While quantitative approaches are in themselves important research methodologies, they are limited in terms of providing deeper insights and understanding regarding the variables studied. Therefore, future studies can use mixed-methodology approaches in weighing the perceptions, ideas, and views of the respondents.

\section{Conclusion}

The aim of the study was to analyze the relationship between organizational culture and transformational leadership style on job performance of the employees at Abu Dhabi Oil National Company. The applied measures of this study have exposed a remarkable level of reliability. two hypotheses were developed, all hypotheses were fully supported. Generally, based on the findings of the study, the transformational leadership behavior and organizational culture have a significant relationship on employees' job performance. In addition, this finding, thus, contributes to the existing literature on the effects of transformational leadership and organizational culture on the job performance of employee, especially in an Oil and Gas context. Therefore, if ADNOC must realize optimal performances from its 
employees, then transformational leadership must be a primary leadership style embraced by the organization.

\section{References}

- Abdullah, M., Ab Hamid, M. R., Mustafa, Z., Idris, F., \& Suradi, N. R. M. (2013). Mediating Effect of Organisational Culture between Leadership Values on Innovation: A Partial Least Squares (Pls) Path-Modeling. Jurnal Teknologi, 63(2).

- Aimran, A. N., Afthanorhan, W. M., \& Razali, N. H. (2015). Moderated Mediation Using Partial Least Square Structural Equation Modeling (PLS-SEM). International Journal of Engineering $\backslash \&$ Technology Research, 3(2), 1-10.

- Al-Husseini, S., \& Elbeltagi, I. (2016). Transformational leadership and innovation: a comparison study between Iraq's public and private higher education. Studies in Higher Education, 41(1), 159-181.

- Ahmadi, A., Rezaei, S., \& Gorizan, L. (2015). Relationship Between Transformational Leadership And Organizational Culture And Employee Silence In National Iranian South Oil Company (2015).

- Al-Ali, A. A., Singh, S. K., Al-Nahyan, M., \& Sohal, A. S. (2017). Change Management through Leadership: The Mediating Role of Organizational Culture. International Journal of Organizational Analysis, 25(4), 723-739.

- Alzahmi Amin, M., Shah, S., \& Tatlah, I. A. (2013). Impact of Principals/Directors' Leadership Styles on Job Satisfaction of the Faculty Members: Perceptions of the Faculty Members in a Public University of Punjab, Pakistan. Journal of Research, 7(2), 97-112.

- Alomiri, H. (2016). The impact of leadership style and organisational culture on the implementation of eservices: an empirical study in Saudi Arabia.

- Avolio, B. \&. (1991). From Transactional to Iransformational Leadership : Learning to Share the Vision, 19-32.
- Avolio, B. J., Bass, B. M., \& Jung, D. I. (1999). Re-Examining the Components of Transformational and Transactional Leadership Using the Multifactor Leadership. Journal of occupational and organizational psychology, 72(4), 441462.

- Avolio, B. J., Waldman, D. A., \& Yammarino, F. J. (1991). Leading in the 1990s: The four I's of transformational leadership. Journal of European industrial training, 15(4).

- Bass, B. M. (1996). A New Paradigm for Leadership: An Inquiry into Transformational Leadership. Tech. rep., DTIC Document.

- Bass, B. M. (1999). Two decades of research and development in transformational leadership. European journal of work and organizational psychology, 8(1), 9- 32.

- Bass, B. M. (2000). The future of leadership in learning organizations. Journal of leadership \\& organizational studies, 7(3), 18-40.

- Bass, B. M., \& Avolio, B. J. (1990). Transformational leadership development: Manual for the multifactor leadership questionnaire. Consulting Psychologists Press Palo Alto, CA.

- Bass, B. M., \& Avolio, B. J. (2000). MLQ: Multifactor leadership questionnaire. Mind Garden.

- Bass. (1985). Leadership and performance beyond expectation. New York: The Free Press.

- Batmanghlich, C. A. (2015). What is Leadership? In Why Leaders Fail Ethically (pp. 5-32). Cham: Springer International Publishing. https://doi.org/10.1007/978-3-31912733-0_2

- Beck-Tauber, D., Choy Chong, L., \& Wüstenhagen, R. (2012). Transformational Leadership: Exploring its Functionality. UniversitätsBuchbinderei Georg Konrad, Munich. Retrieved from https://www1.unisg.ch/www/edis.nsf/S ysLkpByIdentifier/4067/\$FILE/dis4067. pdf 
- Bennett, R. M., Honda, D., Beakes, G. W., \& Thines, M. (2017). Labyrinthulomycota. In Handbook of the Protists (pp. 1-36). Cham: Springer International Publishing. https://doi.org/10.1007/978-3-31932669-6_25-1.

- Berrio, A. A. (2003). An Organizational Culture Assessment Using the Competing Values Framework: A Profile of Ohio State University Extension. Age, 2(699), 1.052 .

- Burns, J. M. (1978). Leadership. New York: Harper \& Row.

- Campbell et al (1993). (n.d.). 1 Chapter 5 Understanding Performance Copyright (C) The McGraw-Hill Companies, Inc. - ppt download. Retrieved December 23, 2018, from https://slideplayer.com/slide/5912626/

- Campbell, J. (1990). Modeling the performance prediction problem in industrial and the impact of HR practices on the performance of business units organizational psychology. Handbook of Industrial and Organizational Psychology (2).

- Dastmalchian, A., Lee, S., \& Ng, I. (2000). The Interplay between Organizational and National Cultures: A Comparison of Organizational Practices in Canada and South Korea Using the Competing Values Framework. International Journal of Human Resource Management, 11(2), 388-412.

- Denison, D., Nieminen, L., \& Kotrba, L. (2014). Diagnosing organizational cultures: A conceptual and empirical review of culture effectiveness surveys. European Journal of Work and Organizational Psychology, 23(1), 145161.

- Denison, D.R. (1996), "What is the Difference Between Organizational Culture and Organizational Climate? A Native's Point of View on a Decade of Paradigm Wars." Academy of Management, Academy of Management Review.

- $\quad$ Esmi, K., Piran, M., \& Hayat, A. A. (2017). The Mediating Effect of Organizational Culture on the Relationship between
Transformational Leadership and Organizational Citizenship Behaviour. Journal of Health Management and Informatics, 4(4), 114-119.

- Finkelstein, S., Hambrick, D., \& Cannella, A. A. (1996). Strategic Leadership. St. Paul: West Educational Publishing.

- Fornell, C., \& Larcker, D. F. (1981). Evaluating Structural Equation Models with Unobservable Variables and Measurement Error. Journal of Marketing Research, 18(1), 39. https://doi.org/10.2307/3151312

- Gopal, R., \& Chowdhury, R. G. (2014). Leadership styles and Employee Motivation: An empirical investigation in a leading oil company in India. International Journal of Research in Business Management (IJRBM), 2(5), 110.

- Golden III, J. H. (2016). Examining Relationships between Transformational Leadership and Employee Creativity and Innovation Performance: The Moderator Effects of Organizational Culture. Northcentral University.

- Hair, J. F., Ringle, C. M., \& Sarstedt, M. (2011). Pls-Sem: Indeed a Silver Bullet. Journal of Marketing theory and Practice, 19(2), 139-152.

- Hair, J. F., Hult, G. T., Ringle, C., \& Sarstedt, M. (2014). A Primer on Partial Least Squares Structural Equation Modeling (PLS-SEM).

- Halim, M. S. B. A., Alremawi, M. S. A. A., \& Tambi, A. M. B. A. (2018). The Mediating Role of Organizational Culture on the Relationship between Employee Performance and Antecedents in the Hotel Sector. Journal of Reviews on Global Economics, 6, 489-497.

- Hambrick, D. C., \& Mason, P. A. (1984). Upper Echelons: The Organization as a Reflection of Its Top Managers. Academy of management Review, 9(2), 193-206.

- Hofstede, G. (2011). Dimensionalizing Cultures: The Hofstede Model in Context. Online readings in psychology and culture, 2(1), 8.

- Hijazi, S. M. M. (2017). The relationship between leadership styles, 
communication competence and employees' job satisfaction in private Universities of the UAE (Doctoral dissertation, Universiti Utara Malaysia).

- James-Parks, Y. M. (2015). A quantitative study of leadership style and church organizational culture (Doctoral dissertation, Capella University).

- Janićijević N. (2008). Organizaciono ponašanje. Beograd: Data status

- Jiang, W., Zhao, X., \& Ni, J. (2017). The impact of transformational leadership on employee sustainable performance: The mediating role of organizational citizenship behaviour. Sustainability (Switzerland), 9(9). https://doi.org/10.3390/su9091567

- Keir, A., \& Youssif, M. (2016). Staff Perceptions of How Human Resource Management Practices Influence Organisational Performance: Mediating Roles of Organisational Culture, Employees' Commitment and Employee Retention in Bahrain Private Universities. Cardiff Metropolitan University,

- Kline, R. B. (2015). Principles and practice of structural equation modeling: Guilford publications.SEP?

- Kişi, N. (2019). Theoretical Perspective on Contemporary Leadership Styles: Transformational and Relational Leadership. In Handbook of Research on Contemporary Approaches in Management and Organizational Strategy (pp. 248-272). IGI Global.

- Mawoli, M. A., Mohammed, T. H., Polytechnic, T. F., \& Mawoli, M. A. (2012). Effect of leadership styles on employees' job performance: evidence from federal medical centre in niger state, 1-15.

- Madhanga, C. S. M. (2018).An investigation into various leadership styles and the impact on employee performance at Subtech Group in KwaZulu-Natal: a case study (Doctoral dissertation).

- Muda, I., Rafiki, A., \& Harahap, M. R. (2014). Factors Influencing Employees' Performance: A Study on the Islamic Banks in Islamic Science University of
Malaysia University of North Sumatera, 5(2), 73-80.

- Muda, I., Rafiki, A., \& Harahap, M. R. (2014). Factors Influencing Employees' Performance: A Study on the Islamic Banks in Islamic Science University of Malaysia University of North Sumatera, 5(2), 73-80.

- Nawaz, Z. A. K. D. A., \& Khan. (2016). Leadership theories and styles: A literature review. Leadership, 16, 1-7.

- Northouse P. (2007). Leadership. Thousand oaks: Sage. Leadership: Theory and Practice: Sage Publications

- Northouse, P. G. (2012). Leadership: Theory and Practice: Sage Publications.

- Northouse, P. G. (2018). Leadership: Theory and practice. Sage publications.

- Northouse, P.G. (2010). Leadership, theory and practice (5th ed.). Los Angeles, Ca.: Sage Publications.

- Northouse. (2012). Introduction to leadership : Concepts and practice, $2, n d$ ed, Los.

- Picon, A., Castro, I., \& Roldon, J. L. (2014). The relationship between satisfaction and loyalty: A mediator analysis. Journal of Business Research, 67(5), 746-751.

- Saad, A. M. \& G. Ben. (2018). Arabian public sector work culture " The impact of organizational culture on job performance: a study of Saudi Arabian public sector work

- Salanova, M., Lorente, L., Chambel, M. J., \& Martínez, I. M. (2011). Linking transformational leadership to nurses' extra-role performance: the mediating role of self-efficacy and work engagement. Journal of advanced nursing, 67(10), 2256-2266.

- Salleh, M. J., Mohamad, N. A., \& Khalid, R. Best Practices of Islamic Leadership Principles Among Principals of Excellent Secondary Schools Malaysia.

- Simon Western, (2008) Emergent Leadership: The Eco-Leader Discourse in Leadership: a critical text. Sage, London, ISBN Paperback ISBN: 9781412923057, Hardcover ISBN: 9781412923040. 
- Simmons, M. J. (2017). Leader selfdevelopment: An emerging strategy for building leadership capacity (Doctoral dissertation, Kansas State University).

- Storey, J., Hartley, J., Denis, J. L., Hart, P. T., \& Ulrich, D. (Eds.). (2016). The Routledge Companion to Leadership. Taylor \& Francis.

- Tafvelin, S. (2013). The Transformational Leadership Process Antecedents, Mechanisms, and Outcomes in the Social Services. UMEA University. Retrieved from www.pixgallery.com

- $\quad$ Taing, M., Bobis, J., Way, J., \& Anderson, J. (2015). Using metaphors to assess student motivation and engagement in mathematics. Proceedings of PME 39, 4, 233-240.

- Tlaiss, H. A., \& Elamin, A. M. (2015). Exploring organizational trust and organizational justice among junior and middle managers in Saudi Arabia: trust in immediate supervisor as a mediator. Journal of Management Development, 34(9), 1042-1060.

- Wang, H., Law, K. S., Hackett, R. D., Wang, D., \& Chen, Z. X. (2005). Leader-Member Exchange as a Mediator of the Relationship between Transformational Leadership and Followers' Performance and Organizational Citizenship Behaviour. Academy of Management Journal, 48(3), 420-432.

- Weerarathna, R. S., \& Geeganage, I. A. P. H. (2014). The Relationship between Organizational Culture and Employee Performance: Case of Sri Lanka. International Journal of Scientific \& Engineering Research, 5(8). Retrieved from http://www.ijser.org

- Yang, J.-T. (2010). Antecedents and Consequences of Job Satisfaction in the Hotel Industry. International Journal of Hospitality Management, 29(4), 609-619.

- Yukl G. (2010). Leadership in Organizations. 7th edition. Upper Saddle River: Pearson. 